\title{
Cavernous Hemangioma of Adult Pancreas: A Case Report and Literature Review
}

\author{
Xiaoxia Lu, Quanxin Yang*, Lei Deng and Ali Shang \\ Department of Radiology, Shaanxi, China
}

*Corresponding author: Quanxin Yang. Department of Radiology, No.157 Xi-Wu Road, Xi'an, 710004, Shaanxi, China

\begin{tabular}{l}
\hline ARTICLE INFO \\
Received: 㓞 February 15, 2021 \\
Published: 㓞 February 22, 2021 \\
\hline
\end{tabular}

Citation: Xiaoxia Lu, Quanxin Yang, Lei Deng, Ali Shang. Cavernous Hemangioma of Adult Pancreas: A Case Report and Literature Review. Biomed J Sci \& Tech Res 34(1)-2021. BJSTR. MS.ID.005498.

\section{Keywords: Pancreas; Cavernous} hemangioma; Computed tomography; Magnetic resonance imaging; Case report

Abbreviations: $\quad \mathrm{CT}=$ Computed Tomography; MRI= Magnetic Resonance Imaging; PPPD: Pylorus Preserving Pancreatoduodenectomy; $\mathrm{SCN}=$ Serous Cystic Neoplasm; MCN= Mucinous Cystic Neoplasm; T1WI= T1-Weighted Images; T2WI=T2-Weighted Images

\begin{abstract}
Rationale: Pancreatic hemangioma is a rare non-epithelial tumor. Because imaging findings are atypical, it is difficult to distinguish pancreatic hemangioma from other cystic tumors of the pancreas. We describe an unusual case of cavernous hemangioma of adult and summarize the radiologic features of it to improve diagnostic accuracy.
\end{abstract}

Patient Concerns: In this report, a 62-year-old male who presented with a threemonth history of abdominal pain.

Diagnosis: The patient was diagnosed initially as serous cystic neoplasm (SCN) of pancreas based on computed tomography (CT) scan, however, pathology confirmed cavernous hemangioma.

Interventions: The patient underwent laparoscopic subtotal pancreatectomy.

Outcomes: The patient was cured, and during follow-up of at least 18 postoperative months, the patient has expressed no complaints or concerns related to his treatment.

Conclusion: Pancreatic hemangioma is rare benign tumor that difficult to diagnose by imaging. The sign of imaging mentioned in this case may have important implications for the diagnosis of pancreatic hemangiomas.

\section{Introduction}

Improvements in imaging technologies have led to a greater frequency of detecting pancreatic cystic lesions. The prevalence of pancreatic cystic lesions has been estimated to be $3 \%$ by CT and up to $20 \%$ by MRI technology [1]. Despite these advances, many benign lesions mimic pancreatic malignancies, often posing challenges to radiologists. Pancreatic hemangioma, a benign tumor, is difficult to diagnose because of a lack of distinguishing features in imaging. Pancreatic hemangiomas are more common in children, and only a few adult cases have been reported [2-29]. We describe a 62-yearold man who underwent resection of pancreatic lesions that were diagnosed eventually as cavernous hemangioma.

\section{Case Report}

Informed consent for publication was obtained from the patient. A 62-year-old male was referred to our hospital after experiencing upper abdominal discomfort for one month. There was no special medical history. Physical examination was normal. Laboratory tests included complete blood counts, serum amylase and lipase, coagulation function, fasting blood glucose, AFP, serum CA19-9 in the normal range; CEA was increased slightly to $3.53 \mathrm{ng} / \mathrm{ml}$. An abdominal CT scan showed a well-circumscribed multilocular cysts lesion with septa measuring $6.3 \mathrm{~cm} \times 4.2 \mathrm{~cm} \times 4.4 \mathrm{~cm}$ in the tail of the pancreas (Figure 1A). Markedly enhanced septa in the shape of spoke-wheel were observed after injection of contrast agent (Figure 1B). The degree of lesion enhancement was decreased at portal vein phase (Figure 1C) and delayed phase (Figure 1D).

The patient underwent laparoscopic subtotal pancreatectomy. During the surgery, the tail of the pancreas was tightly adhered to the splenic hilum, after communicated with families, the surgeon decided to perform splenectomy. Gross pathology showed a brownish, multi-loculated, partly hemorrhagic, and approximately $6.5 \mathrm{~cm} \times 4.5 \mathrm{~cm} \times 5.0 \mathrm{~cm}$ cystic mass with a clear boundary. 
Pathological examination showed that the tumors were composed of dilated cavernous vessels filled with red blood cells, endothelial cells lining the wall of the lacunae (Figure 2A,2B) and the spleen was normal. Final diagnosis in this case was a cavernous hemangioma of the pancreas. During follow-up of at least 18 postoperative months, the patient has expressed no complaints or concerns related to his treatment.
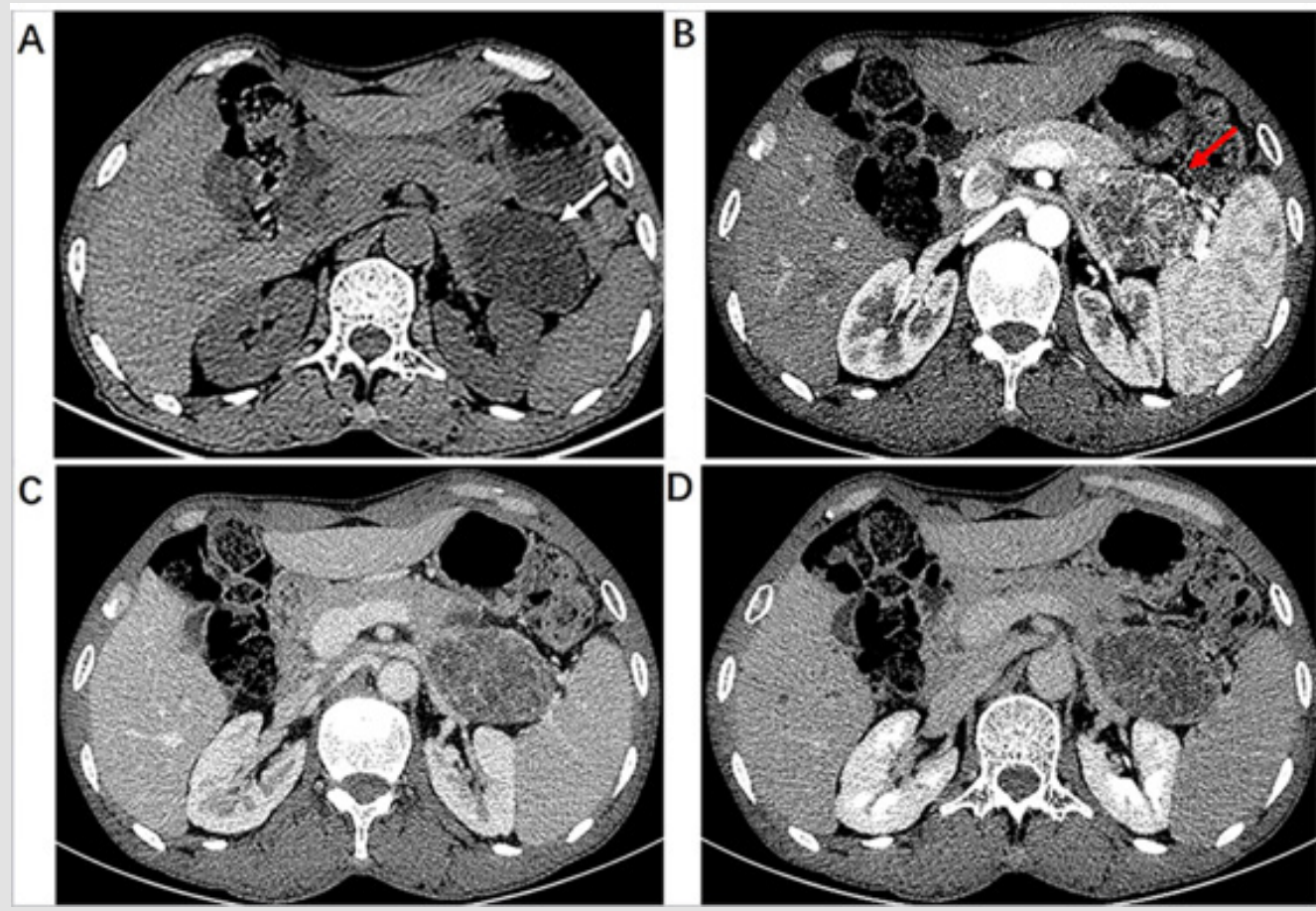

Figure 1: 62-year-old male with pancreatic hemangioma. (A) Plain CT scan of upper abdomen showed well-circumscribed multilocular cysts with septa lesion in the tail of the pancreas (white arrow). (B) Enhanced CT scan at arterial phase demonstrated a mass with markedly enhanced septa in the shape of spoke-wheel (red arrow). Portal vein phase (C) and delay phase(D) showed the enhanced reduction of the separations.
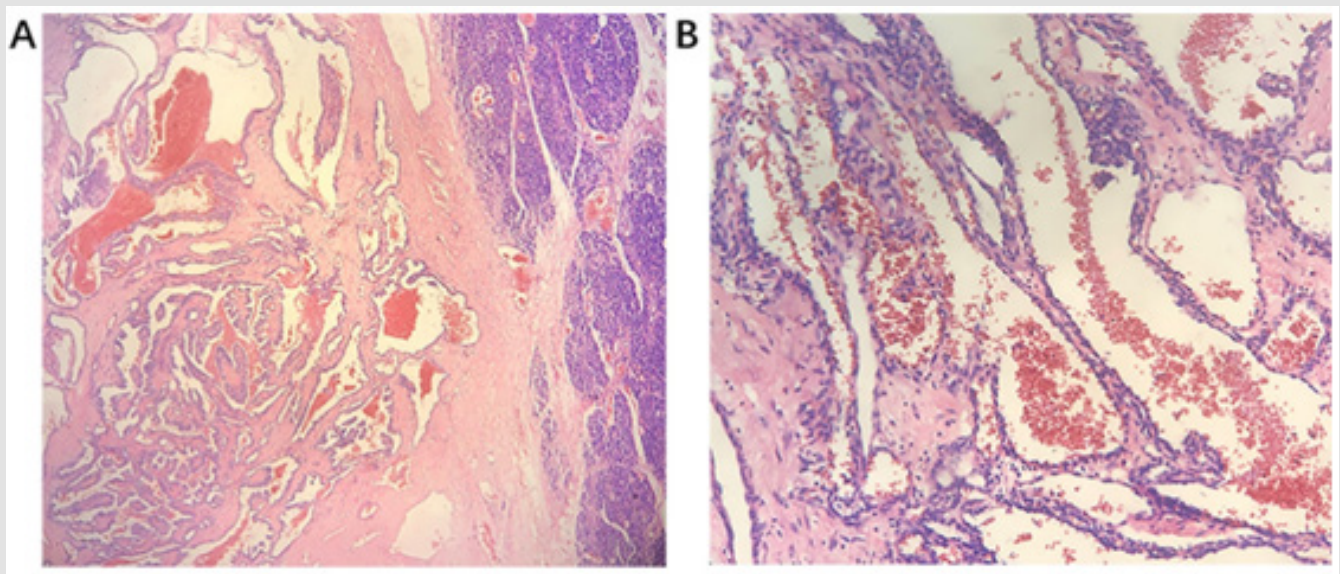

Figure 2: (A)H\&E staining of the tumor showing a multiple expanded cavernous blood vessel containing red blood cells. The right side is normal pancreatic tissue (HE 40×). (B) Some of the vessels in the lesion had thick walls characterized by proliferating multilayer endothelial cells, and other vessels had thin walls with a single layer of flattened cells (HE 100×).

\section{Discussion}

Vascular tumors of the pancreas constitute only $0.1 \%$ of all pancreatic tumors [30] (hemangioma, lymphangioma, hemolymph angioma, hemangioendothelioma, hemangiopericytoma, hemangioblastoma, and angiosarcoma). To our knowledge, only 31 cases have been reported since 1939, three of these 31 cases were mentioned by $\mathrm{Xu}$, et al. [10]. Details of these cases are summarized in Table 1. Review of the literature indicated that most hemangiomas occurred in females. The common symptoms were abdominal pain, and the lesions were usually located at the head of pancreas. 
Table 1: Adult pancreatic hemangiomas reported in the literature.

\begin{tabular}{|c|c|c|c|c|c|c|c|c|}
\hline Case & Year & Author/Ref. & Age & Sex & Presentation & Site & $\operatorname{Size}(\mathrm{cm})$ & Treatment \\
\hline 1 & 1939 & Ranström [2] & 61 & $\mathrm{~F}$ & - & Head & 7 & - \\
\hline 2 & 1961 & Ringoir, et al. [3] & 71 & $\mathrm{~F}$ & $\begin{array}{l}\text { Hematemesis/ } \\
\text { melaena }\end{array}$ & Head & 15 & Gastroenterostomy, vagotomy \\
\hline 3 & 1972 & Colardyn, et al. [4] & 42 & $\mathrm{~F}$ & Abdominal pain & Body & - & Fat-free diet, anticholinergics \\
\hline 4 & 1985 & Mangin, et al. [5] & 62 & $\mathrm{~F}$ & Malaise, nausea, & $\begin{array}{l}\text { Head to tail } \\
\text { thrombocytopenia }\end{array}$ & 20 & Removal of the tumour \\
\hline 5 & 1991 & Kobayashi, et al. [6] & 30 & M & Abdominal distension & Head & 20 & Pancreatoduodenectomy \\
\hline 6 & 1991 & Dageforde, et al. [7] & 79 & $\mathrm{~F}$ & Abdominal pain & Body to tail & 6 & Observation \\
\hline 7 & 2003 & Chang, et al. [8] & 70 & $\mathrm{~F}$ & Abdominal pain & Body to tail & 4 & $\begin{array}{l}\text { Distal subtotal } \\
\text { pancreatectomy }\end{array}$ \\
\hline 8 & 2006 & Plank, et al. [9] & 36 & M & Abdominal pain & Head & 3 & $\begin{array}{l}\text { Laparotomy without } \\
\text { resection, observation }\end{array}$ \\
\hline \multirow[t]{3}{*}{9} & 2008 & Xu, et al. [10] & 60 & $\mathrm{~F}$ & $\begin{array}{l}\text { Abdominal } \\
\text { pain?fever }\end{array}$ & Tail & 2 & $\begin{array}{l}\text { Pancreatectomy body/ tail, } \\
\text { splenectomy }\end{array}$ \\
\hline & & & 30 & $\mathrm{~F}$ & Abdominal pain & Head & 6 & pancreatico-duodenectomy \\
\hline & & & 41 & $\mathrm{~F}$ & - & Body & 2.5 & $\begin{array}{l}\text { Pancreatic body } \\
\text { segmentectomy }\end{array}$ \\
\hline 10 & 2009 & Mundinger, et al. [11] & 45 & $\mathrm{~F}$ & Abdominal pain & Head & 6.2 & PPPD \\
\hline 11 & 2010 & Jarboui, et al. [12] & 62 & $\mathrm{~F}$ & Abdominal pain & Body & 2.3 & $\begin{array}{l}\text { Distal pancreatectomy } \\
\text { splenectomy }\end{array}$ \\
\hline 12 & 2011 & Weidenfeld, et al. [13] & 73 & $\mathrm{~F}$ & Abdominal pain & Head & 5.5 & Whipple's procedure \\
\hline 13 & 2011 & Lee, et al. [14] & 49 & $\mathrm{~F}$ & $\begin{array}{c}\text { Incidental US } \\
\text { finding, non- specific } \\
\text { dizziness }\end{array}$ & Neck & 5 & Central pancreatectomy \\
\hline 14 & 2012 & Malik, et al. [15] & 70 & $\mathrm{~F}$ & Abdominal pain & Head & 7.9 & PPPD \\
\hline 15 & 2013 & Shibata, et al. [16] & 79 & M & - & Body & 1 & $\begin{array}{l}\text { Distal pancreatectomy } \\
\text { splenectomy }\end{array}$ \\
\hline 16 & 2013 & Bursics, et al. [17] & 72 & M & $\begin{array}{l}\text { Abdominal pain, } \\
\text { fever, jaundice }\end{array}$ & Head & 8.7 & PPPD \\
\hline 17 & 2013 & Lu, et al. [18] & 23 & $\mathrm{~F}$ & - & Head & 5 & subtotal pancreatectomy \\
\hline 18 & 2014 & Williamson, et al. [19] & 78 & $\mathrm{~F}$ & Abdominal pain & Head & 4 & Observation \\
\hline 19 & 2014 & Naito, et al. [20] & 40 & $\mathrm{~F}$ & Abdominal pain & Body to tail & 10 & Pancreatectomy \\
\hline 20 & 2015 & Mondal, et al. [21] & 18 & $\mathrm{~F}$ & Abdominal pain & Head & 5 & PPPD \\
\hline 22 & 2015 & Soreide, et al. [22] & 30 & $\mathrm{~F}$ & $\begin{array}{l}\text { Abdominal pain, } \\
\text { gestation } 12 \text { weeks }\end{array}$ & Tail & 19.5 & $\begin{array}{c}\text { Distal pancreatectomy, } \\
\text { splenectomy }\end{array}$ \\
\hline 23 & 2015 & Lu, et al. [23] & 28 & $\mathrm{~F}$ & Abdominal pain & Body to tail & 10 & $\begin{array}{l}\text { Subtotal pancreatectomy, } \\
\text { splenectomy }\end{array}$ \\
\hline 21 & 2016 & Kim, et al. [24] & 68 & M & - & Tail & 0.5 & Distal pancreatectomy \\
\hline 24 & 2017 & Al Warith, et al. [25] & 71 & $\mathrm{~F}$ & Left iliac fossa pain & Tail & 2.4 & $\begin{array}{c}\text { Laparoscopic distal } \\
\text { pancreatectomy, splenectomy }\end{array}$ \\
\hline 25 & 2018 & Raymundo, et al. [26] & 36 & M & Lumbar pain & Body to tail & 2.4 & $\begin{array}{l}\text { Pancreatectomy body/ tail, } \\
\text { splenectomy }\end{array}$ \\
\hline 26 & 2018 & Koo, et al. [27] & 62 & $\mathrm{~F}$ & $\begin{array}{l}\text { Hematemesis, } \\
\text { hemoptysis, } \\
\text { Abdominal pain }\end{array}$ & Head & 5.5 & Whipple's procedure \\
\hline 27 & 2018 & Torres, et al. [28] & 56 & M & - & Tail & - & - \\
\hline 28 & 2019 & Tao, et al. [29] & 63 & M & Abdominal pain & Head & 10 & Pancreaticoduodenectomy \\
\hline 29 & 2019 & Present case & 62 & M & Abdominal pain & Tail & 6.3 & $\begin{array}{l}\text { Pancreatectomy body/tail, } \\
\text { splenectomy }\end{array}$ \\
\hline
\end{tabular}


CT and MRI are the main methods used to diagnose pancreatic cavernous hemangioma. As a benign tumor, typically, pancreatic hemangiomas were described as well-circumscribed with homogeneous lower density and intense enhancement on CT after injection of contrast material [6,8,9,11]. Ahmed, et al. [15] described pancreatic hemangiomas imaging features which were like liver giant hemangiomas with peripheral nodular enhancement and progressive centripetal enhancement. However, many studies have shown that significant enhancement in the arterial phase is not a common manifestation of pancreatic cavernous hemangioma $[6,8,11-14,17,18]$, it may be because pancreatic cystic tumors usually contain areas of neovascularization, and the ratio of cystic to solid tissue affects the degree of tumor vessel distribution, which could also influence expected arterial phase signal intensity $[6,8,11]$. Lu, et al. [18] described pancreatic hemangioma as multilocular cysts with fluid-fluid levels and no obvious enhancement. Above all, a poor arterial phase enhancement on CT scan cannot rule out a diagnosis of pancreatic hemangioma. Ten of the reported cases underwent MRI, but only one case, reported by Kobayashi, et al. [6], showed typical hypo intensity in T1WI and moderate hyper-intensity signal in T2WI with marked enhancement postgadolinium. However, Plank, et al. [9] showed that pancreatic hemangioma appeared only moderately hyperintense on T2WI images and did not reveal uptake of contrast agent into the mass. Kobayashi, et al. [6] suggested that MRI, especially T2WI imaging, can be used as an alternative method to show whether blood is the main component of the tumor.

In our case, however, the imaging findings were completely different from previous reports. The most significant feature of the mass on CT was the intense enhancement of the septa in the shape of spoke-wheel displayed in arterial phase. As far as we know, this case was the first to exhibit this imaging feature. For pancreatic hemangiomas, especially manifested as cystic mass with multiple internal partitions, clinicians need to consider several different diagnoses:

a) Pancreatic SCN usually found in middle-aged and elderly women. Most SCN has been described as multiloculated cystic masses with central scar with or without calcifications (seen in $30 \%$ of cases) [31].

b) MCN is seen usually in postmenopausal women. Most of the MCNs are in the body or tail of the pancreas and are predominantly macrocytic, sometimes with characteristic peripheral eggshell-like calcifications.

MCN may be malignant when present as thick internal septations and wall nodules [32]. In the case presented here, the well-circumscribed multilocular cysts lesion located in the tail of the pancreas without wall nodules was diagnosed initially as SCN, however, pathology confirmed cavernous hemangioma.

Although pancreatic hemangioma is a benign tumor, it can be difficult to differentiate them from epithelial tumors of the pancreas, also because of the risk of bleeding [27], surgical excision is still the best treatment in adults. Most patients who underwent pancreas hemangioma resection have good prognosis [10,20,21]. According to the location of the tumor in pancreas, different resection methods could be choose. Tumors located in the head of the pancreas have been treated by pancreaticoduodenectomy in most cases [6,10,11,15,17,21,27,29]. Tumors located in the body and tail of the pancreas $[8,12,16,22,24,25]$ have been treated by local resection with spleen preservation or partial excision. Different from adult patients, pancreatic hemangiomas tend to heal spontaneously in children, therefore, follow-up observation is recommended.

\section{Conclusion}

Pancreatic hemangioma is rare benign tumor with no imaging characteristics. It should be considered as a differential diagnosis of multilocular cystic pancreatic masses. Except for a few cases that are markedly enhanced of the lesion, such as hepatic hemangiomas, pancreatic hemangiomas tend to have no significant enhancement and fluid-fluid levels that may be caused by bleeding, or with the intense enhancement of septa with a spoke-wheel shaped displayed in arterial phase in our case. These signs may have important implications for the diagnosis of pancreatic hemangiomas. Increasing awareness of pancreatic hemangiomas can reduce unnecessary surgery and relieve patient psychological and financial burdens.

\section{Consent for Publication}

Written informed consent was obtained from the patient for publication of the case details and accompanying images.

\section{Funding References}

No funding was received.

\section{Availability of Data and Materials}

The authors declare that all data supporting the findings of this study are available within the article. No datasets were generated or analyzed during the current study.

\section{Authors' Contributions}

Study conception and design: Quanxin Yang. Data acquision : Xiaoxia Lu, Ali Shang. Drafting of the manuscript: Xiaoxia Lu. Manuscript revision: Lei Deng. All authors read and approved the final manuscript.

\section{Competing Interests}

The authors declare that they have no competing interests.

\section{References}

1. Del Chiaro M, Verbeke C, Salvia R, Gunter K, Jens W, et al. (2013) European experts consensus statement on cystic tumours of the pancreas. Digestive and Liver Disease 45(9): 703-711.

2. Ranström V (1939) Haemangioma cavernosum pancreatis. Zentralblatt für allgemeine pathologie und pathologische 73(2): 33-35. 
3. S R, F D, R C, G M (1961) Hemangioma of the pancreas. Report of a case. Gastroenterology 41.

4. Colardyn F, Elewaut A, Van de Velde E, Barbier F (1972) Hemangioma of the pancreas. Tijdschrift voor gastro-enterologie 15(4): 260-267.

5. Mangin P, Perret M, Ronjon A (1985) Hemangioma of the pancreas. Journal de radiologie 66(5): 381-384.

6. Kobayashi H, Itoh T, Murata R, Tanabe M (1991) Pancreatic cavernous hemangioma: CT, MRI, US, and angiography characteristics. Gastrointest Radiol 16(4): 307-310.

7. Dageforde J, Gmelin E, Otte M (1991) Hemangioma of the pancreas. Rofo 154(3): 332-333.

8. Chang WT, Lee KT, Yang SF (2003) Cavernous hemangioma of the pancreas: report of a case. Pancreas 26(3): 310-312

9. Plank C, Niederle B, Ba-Ssalamah A, Schimaa W (2006) Pancreatic hemangioma: Imaging features with contrast-enhanced CT and with gadolinium- and mangafodipir-enhanced MRI. European Journal of Radiology Extra 57(2): 59-62.

10. Xu Q, Wang C-F, Zhao P, Shan Y, Zhao D-B, et al. (2008) The diagnosis and treatment of pancreatic cavernous hemangioma. Zhonghua yi xue za zhi 88(1): $28-30$

11. Mundinger GS, Gust S, Micchelli ST, Fishman EK, Hruban RH, et al. (2009) Adult Pancreatic Hemangioma: Case Report and Literature Review. Gastroenterology Research and Practice.

12. S J, A S, S GB, M Ben M, H Rajhi, et al. (2010) Hemangioma of the pancreas in a 60-year-old woman: a report of a new case. Gastroenterologie Clinique et Biologique 34(10): 569-571.

13. Weidenfeld J, Zakai BB, Faermann R, Barshack I, Aviel-Ronen S (2011) Hemangioma of pancreas: a rare tumor of adulthood. Isr Med Assoc J 13(8): 512-514.

14. Lee J, Raman K, Sachithanandan S (2011) Pancreatic hemangioma mimicking a malignant pancreatic cyst. Gastrointest Endosc 73(1): 174176.

15. Ahmed I, Malik M, Kurban L, Malik M, Ahmed I (2013) Pancreatic Hemangioma - A Case Report. Journal of Gastroenterology and Hepatology Research 2(4): 545-548.

16. Shibata T, Matsuo Y, Fujihata S (2013) Adult pancreatic cavernous hemangioma: A case report. Pancreatology 13(4): S69.

17. Bursics A, Gyokeres T, Bely M, Porneczi B (2013) Adult hemangioma of the pancreas: difficult diagnosis of a rare disease. Clin J Gastroenterol 6(4): 338-343.

18. Lu ZH, Wu M (2013) Unusual features in an adult pancreatic hemangioma: CT and MRI demonstration. Korean J Radiol 14(5): 781-785.

ISSN: 2574-1241

DOI: $10.26717 /$ BJSTR.2021.34.005498

Quanxin Yang. Biomed J Sci \& Tech Res

This work is licensed under Creative

Commons Attribution 4.0 License

Submission Link: https://biomedres.us/submit-manuscript.php
19. Williamson JM, Finch-Jones M, Pope I (2014) Endoscopic ultrasonography allowing expectant management of pancreatic haemangioma. Ann R Coll Surg Engl 96(3): e1-2

20. Naito Y, Nishida N, Nakamura Y (2014) Adult pancreatic hemangioma: A case report. Oncol Lett 8(2): 642-644.

21. Mondal U, Henkes N, Henkes D, Rosenkranz L (2015) Cavernous hemangioma of adult pancreas: A case report and literature review. World J Gastroenterol 21(33): 9793-9802.

22. Soreide JA, Greve OJ, Gudlaugsson E (2015) Adult pancreatic hemangioma in pregnancy--concerns and considerations of a rare case. BMC Surg 15(1): 119.

23. Tao L, Cheng Y (2015) Rare case of adult pancreatic hemangioma and review of the literature. World journal of gastroenterology 21(30).

24. Kim SH, Kim JY, Choi JY, Choi YD, Kim KS (2016) Incidental detection of pancreatic hemangioma mimicking a metastatic tumor of renal cell carcinoma. Korean J Hepatobiliary Pancreat Surg 20(2): 93-96.

25. Al Warith AH, Xavier L, Régis F, Antoine C (2017) Report of a case of pancreatic hemangioma: A difficult preoperative diagnosis. International Journal of Case Reports and Images (IJCRI) 8(9): 575-578.

26. Raymundo SRO, Hussain KMK, Hussein KG, Kuga ML (2018) Rare case of adult pancreatic haemangioma and literature review. BMJ Case Rep 2018(1).

27. Koo CH, Koh YX, Hennedige T, Thng CH, Chung AY (2018) Pancreatic Haemangioma: An Unusual Case of Massive Upper Gastrointestinal Bleeding with Clinical and Radiological Correlation of the Literature and Recommendations. Ann Acad Med Singapore 47(8): 345-348.

28. Torres US, Matsumoto C, de Macedo Neto AC, RP Caldana, Angela HM, et al. (2018) Common and Uncommon Benign Pancreatic Lesions Mimicking Malignancy: Imaging Update and Review. Semin Ultrasound CT MR 39(2): 206-219.

29. Lianyuan T, Yafeng W, Haibo Y, Dong Y, Ma J, et al. (2019) Adult pancreatic cavernous hemangioma: case presentation of a benign tumor with a complex composition. BMC Gastroenterol 19(1): 197.

30. Le Borgne J, de Calan L, Partensky C (1999) Cystadenomas and cystadenocarcinomas of the pancreas: a multiinstitutional retrospective study of 398 cases. French Surgical Association. Ann Surg 230(2): 152161.

31. Chu LC, Singhi AD, Haroun RR, Hruban RH, Fishman EK (2017) The many faces of pancreatic serous cystadenoma: Radiologic and pathologic correlation. Diagn Interv Imaging 98(3): 191-202.

32. Sakorafas GH, Smyrniotis V, Reid-Lombardo KM, Sarr MG (2011) Primary pancreatic cystic neoplasms revisited: part II. Mucinous cystic neoplasms. Surg Oncol 20(2): e93-101.

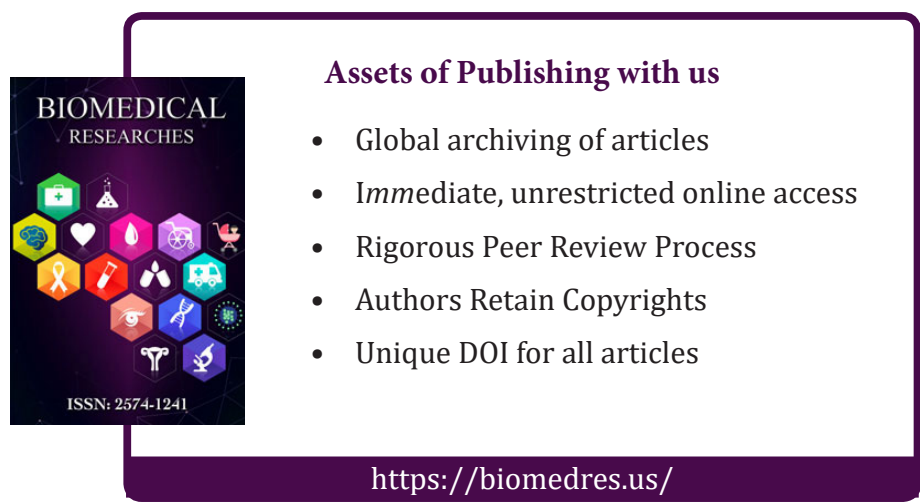

